\title{
$\frac{100}{\text { LAT RPETS }}$
}

\section{KLAUZULE EARNOUT ORAZ CLAWBACK W UMOWACH SPRZEDAŻY NIERUCHOMOŚCI}

\section{UWAGI OGÓLNE}

Potrzeby współczesnego obrotu w zakresie elastyczności postanowień umownych są bardzo duże. Transakcje mające za przedmiot nieruchomości o dużej wartości, angażujące często kapitał zagraniczny, niejednokrotnie wymagają szczególnych rozwiązań prawnych. Takie jest też oczekiwanie stron transakcji - że wszystkie ich cele biznesowe da się implementować do ważnej i skutecznej umowy. Dotyczy to w szczególności określenia ceny nieruchomości, a ściślej: możliwości jej podwyższenia lub obniżenia już po zawarciu umowy sprzedaży przenoszącej własność nieruchomości.

W tym zakresie podnoszone sa jednak wątpliwości co do dopuszczalności wprowadzania do umowy takich rozwiązań - w szczególności właśnie w odniesieniu do umów sprzedaży nieruchomości ${ }^{1}$. Wynika to z regulacji zawartej w art. 157 §.c., zgodnie z którym własność nieruchomości nie może być przeniesiona pod warunkiem ani z zastrzeżeniem terminu ${ }^{2}$. Powstaje więc pytanie, czy te wątpliwości są zasadne, a jeśli tak, jakie rozwiązanie należy przyjąć w umowie sprzedaży nieruchomości ${ }^{3}$, by zapewnić jej ważność i skuteczność, a równocześnie oddać biznesowy zamiar stron. Celem niniejszego opracowania jest podjęcie próby udzielenia odpowiedzi na te pytania.

" Barbara Jelonek-Jarco, Uniwersytet Jagielloński, barbara.jelonek-jarco@uj.edu.pl,https://orcid.org/0000-0003-0418-2414.

${ }^{1}$ Maciak (2014): 43.

${ }^{2}$ Co do art. 157 k.c. zob. Swaczyna (2012): 123-124.

3 Jak również prawa użytkowania wieczystego. 


\section{KLAUZULE ZAPEWNIAJĄCE ELASTYCZNOŚĆ CENY}

W pierwszej kolejności konieczne jest przedstawienie klauzul umownych, które zapewniają elastyczność ceny, a mianowicie: earnout oraz clawback.

Klauzulą earnout określa się mechanizm kalkulacji ceny w umowie sprzedaży, który zapewnia dodatkową płatność (wzrost ceny) na rzecz sprzedawcy w przypadku zaistnienia określonych przez strony zdarzeń ${ }^{4}$. Może to być przykładowo uzyskanie pozwolenia na budowę na określoną powierzchnię użytkowa czy wynajęcie (skomercjalizowanie) dodatkowej powierzchni biurowej w określonym terminie. Mechanizm ten z jednej strony zabezpiecza sprzedawcę, dając mu szansę uzyskania wyższej ceny w przypadku, gdy już po zawarciu umowy sprzedaży nastapią wydarzenia mające pozytywny wpływ na wartość nieruchomości, a z drugiej - zabezpiecza kupującego, który w chwili zawarcia umowy płaci cenę, jaką uznaje za adekwatna, licząc się jednocześnie z możliwościa jej podwyższenia w określonych przypadkach. Cena określona w standardowy sposób nie zawsze odzwierciedla rzeczywistą wartość nieruchomości, a przede wszystkim jej potencjał ekonomiczny. Oczywiście teoretycznie strony moga poczekać z transakcją kilka miesięcy i zawrzeć umowę dopiero po uzyskaniu pozwolenia na budowę, z którego będzie już wynikała określona powierzchnia użytkowa budynku albo dopiero po skomercjalizowaniu całego budynku biurowego, jednak nie takie sa potrzeby praktyki i biznesu. Inwestorzy działaja tu i teraz (co zwykle wynika z planów budżetowych), ale równocześnie nie chca rezygnować z potencjału, jaki ma dana transakcja. Klauzula earnout daje właśnie tę elastyczność - innymi słowy polega ona na podziale ceny na dwie części: pierwsza, której wysokość jest znana w chwili zawarcia umowy i co do zasady wtedy płatna, oraz druga, której wysokość nie jest znana w chwili zawarcia umowy i której obowiązek zapłaty może nigdy nie powstać 5 . W literaturze niemieckiej podkreśla się trafnie, że klauzula earnout ułatwia stronom dojście do porozumienia co do ceny (nie ma bowiem wątpliwości, że co do zasady to właśnie negocjowanie ceny zajmuje stronom najwięcej czasu), a równocześnie w pewien sposób niejako neutralizuje asymetrię informacyjną istniejąca między stronami w chwili zawarcia umowy ${ }^{6}$. Nawet mimo przeprowadzenia dokładnego badania due diligence kupujacy nigdy nie ma bowiem dokładnie takich samych informacji jak sprzedawca.

Klauzule earnout mogą być skonstruowane w sposób dość prosty, czasem natomiast strony umowy sięgają do skomplikowanych algorytmów. Ważne jest jednak to, by zasady dotyczące podwyższenia ceny były określone w sposób precyzyjny - zarówno co do tego, w jaki sposób ma ona być kalkulowana, jak i co do określenia zdarzeń (i terminów), których zaistnienie skutkować

\footnotetext{
${ }^{4}$ Maciak (2014): 43; na gruncie prawa niemieckiego istotę tej klauzuli określa się: „EarnOut-Klauseln sind vertragliche Regelungen, mit denen ein Teil des zu zahlenden Kaufpreises vom Eintritt bestimmter Bedingungen abhängig gemacht wird"; Werner (2012): 1662.

5 Poźniak-Niedzielska (2000): 14.

6 Werner (2012): 1662.
} 
będzie podwyższeniem ceny ${ }^{7}$. Co oczywiste, jeśli przesłanki dla dodatkowej płatności nie ziszczą się, cena nie ulegnie podwyższeniu. Zwykle to sprzedawca ma pełną możliwość działania tak, by dodatkowa płatność uzyskać (przykładowo, to on prowadzi postępowanie administracyjne dotyczące pozwolenia na budowę czy podejmuje działania mające na celu znalezienie kolejnych najemców w określonym czasie i na określonych zasadach). Wtedy sprzedawca kontroluje stan postępowań bądź kieruje działaniami, od których powodzenia zależy wzrost ceny. Czasem jednak - jak wynika z orzecznictwa - sprzedawca przekazuje możliwość działania kupującemu (co niejednokrotnie później skutkuje zarzutami, że nie działał on należycie $\left.{ }^{8}\right)$.

Natomiast klauzula clawback pozwala na obniżenie ceny w przypadku, gdy okazuje się, że w umowie sprzedaży wartość przedmiotu sprzedaży została przeszacowana. Mechanizm ten pozwala więc na ponowne przeliczenie ceny według zasad określonych w umowie i w konsekwencji może prowadzić do jej obniżenia ${ }^{9}$.

Przy czym podkreślenia wymaga, że w praktyce stosowane są różne mechanizmy realizacji wyżej wymienionych klazul. Tak więc wynikająca z nich zmiana ceny (i) może następować automatycznie, bądź (ii) na mocy oświadczenia woli jednej strony lub obu stron umowy (szerzej o dopuszczalności stosowania takich rozwiązań zob. pkt V).

\section{SPOSOBY OKREŚLENIA CENY W UMOWIE SPRZEDAŻY}

Po przedstawieniu uwag natury ogólnej dotyczących istoty omawianych tu klauzul należy przejść do analizy przepisów Kodeksu cywilnego o umowie sprzedaży, a szczególności tego, w jaki sposób może w niej zostać określona cena.

Zgodnie z art. 535 k.c. przez umowę sprzedaży sprzedawca zobowiąuje się przenieść na kupującego własność rzeczy i wydać mu rzecz, a kupujący zobowiązuje się rzecz odebrać i zapłacić sprzedawcy cenę. $\mathrm{Z}$ art. 535 k.c. wynika więc, że drugim istotnym postanowieniem umowy sprzedaży - obok określenia przedmiotu sprzedaży - jest cena. Cena może być określona wprost jako konkretna kwota, ale można ją określić także przez wskazanie podstaw do jej ustalenia (art. $536 \S 1$ k.c.).

Przyjmuje się, że brak ustalenia ceny (podstaw do jej ustalenia) należy traktować jako brak uzgodnienia elementu przedmiotowo istotnego umowy sprzedaży ${ }^{10}$. Jeśli chodzi o skutki braku określenia ceny bądź podstaw do jej ustalenia w umowie sprzedaży, to przeważający jest pogląd, że jest to

${ }^{7}$ Poźniak-Niedzielska (2000): 17; Vischer (2002): 511.

${ }^{8}$ Wyrok SA w Krakowie z 29 maja 2013 r., I ACa 441/13, Legalis; wyrok SA w Krakowie z 8 maja 2018 r., I ACa 909/17, Legalis.

${ }_{9}$ Maciak (2014): 45.

10 Jezioro (2019a): nb. 37. 
nieważnośćc ${ }^{11}$. Prezentowane jest jednak także stanowisko, zgodnie z którym $\mathrm{w}$ braku uzgodnienia $\mathrm{w}$ umowie ceny albo podstaw do jej ustalenia $\mathrm{w}$ przyszłości umowa sprzedaży nie dochodzi do skutku, gdyż nie uzgodniono jej istotnego elementu ${ }^{12}$. Ze względu na zakres niniejszej publikacji nie jest celowe szersze odniesienie się do tej kwestii, jak również problemu ewentualnego uznania takiej czynności prawnej za nieistniejącą ani też dyskusji dotyczącej celowości wyróżniania pojęcia czynności prawnej nieistniejącej ${ }^{13}$.

Podkreśla się, że podstawy do ustalenia ceny muszą być stabilne i konkretne, określone w sposób stanowczy i jednoznaczny ${ }^{14}$. Trafnie nie dopuszcza się możliwości pozostawienia kwestii ustalenia ceny swobodnemu uznaniu wyłącznie jednej ze stron umowy sprzedaży - przyznanie jednej ze stron umowy tak daleko idącej kompetencji stałoby bowiem w sprzeczności z istotą umowy sprzedaży, dawałoby jej zbyt dużą swobodę i jednocześnie powodowałoby powstanie nadmiernego stanu niepewności u drugiej strony. Z tego względu takie postanowienie umowne należy uznać za sprzeczne z zasadami współżycia społecznego, co skutkuje nieważnością umowy sprzedaży ${ }^{15}$.

W literaturze wskazuje się na brak w Kodeksie cywilnym regulacji odpowiadającej art. 297 i 298 k.z. ${ }^{16}$ i skutki z tego wynikajace ${ }^{17}$. Zgodnie z art. 297 k.z.: „Jeżeli określenie ceny pozostawiono słusznemu uznaniu jednej ze stron lub osoby trzeciej, w razie sporu sąd cenę ustali". Przyjmowano, że przepis ten nie znajdował zastosowania, gdy cena miała zostać ustalona przez stronę całkowicie dowolnie (a więc nie było to pozostawione jej „słusznemu” uznaniu) - wtedy $\mathrm{w}$ braku zgodnego ustalenia ceny umowę należy uznać za nieważną ${ }^{18}$. Stosownie natomiast do art. 298 k.z.: „Brak określenia ceny przez strony nie pociaga za sobą nieważności sprzedaży, jeżeli z okoliczności wynika, że strony miały na myśli zwykłe ceny przyjęte w ogóle w obrocie lub w ich stosunkach wzajemnych". Przepis ten znajdował zastosowanie wtedy, gdy strony w umowie nie określiły ceny wprost ani poprzez wskazanie podstaw do jej ustalenia w przyszłości, przy czym obie strony musiały działać w przekonaniu, że chodzi o „cenę zwykłą” ${ }^{2}$.

11 Wyrok SN z 5 lutego 2002 r., II CKN 726/00, Legalis; Katner (2017): 957; Kozioł (2018): nr 30; Trzaskowski (2017): pkt 49-50; Habryn-Chojnacka (2019b): nb. 1; Haładyj, Tulibacka (2020b): nb. 1.

${ }^{12}$ Karasek (2005): nr 1; podobnie Jasińska (2019: nb. 1), która wskazuje, że bez uzgodnienia ceny w ogóle nie dochodzi do zawarcia umowy, oraz Więzowska-Czepiel (2014: nb. 3), która podkreśla: „Należy jednak przyjąć, że nieoznaczenie ceny powoduje, że czynność taka nie została dokonana, jest to czynność nieistniejąca”; wyrok SN z 2 grudnia 2004 r., V CK 291/04, Legalis.

${ }^{13}$ Gutowski (2008): 236, zob. też 66 i n.; Machnikowski (2005): 146 i 364; zob. też Gizbert-Studnicki (1975): 72 .

14 Te wymagania należy odnieść wprost do przedwstępnej umowy sprzedaży, co do określenia ceny sprzedaży w tej umowie; zob. wyroki SN: z 25 czerwca 2008 r., III CSK 20/08, Legalis; z 8 września 2017 r., II CSK 877/16, Legalis.

15 Habryn-Chojnacka (2019b): nb. 2; Jezioro (2019b): nb. 4; odmiennie Skapski (1976): 51-53.

16 Rozporządzenie Prezydenta Rzeczypospolitej - Kodeks zobowiązań z 27 października 1933 r., Dz. U. 1933, Nr 82, poz. 598 ze zm.

17 Katner (2008): 543.

18 Korzonek, Rosenbluth (1936): 787.

19 Korzonek, Rosenbluth (1936): 789. 
Wobec niezamieszczenia w kodeksie cywilnym regulacji odpowiadajacej art. 298 k.z. należy uznać, że nie jest zasadne stanowisko przyjęte przez Sąd Apelacyjny w Katowicach w wyroku z 18 stycznia 1991 r. ${ }^{20}$, zgodnie z którym „Umowa jest ważna, mimo iż strony nie określiły ceny ani nie wskazywały podstaw do jej ustalenia, jeżeli tylko okoliczności towarzyszące zawarciu umowy pozwalają na przyjęcie zgodnej woli stron związania się ceną przyjęta w stosunkach danego rodzaju. Strony nie zawsze ustalają cenę, a zawarcie umowy następuje przez fakty dokonane w sposób dorozumiany" ${ }^{21}$. Pogląd taki mógłby być jednak, mimo niefortunnego sformułowania, trafny na gruncie konkretnego stanu faktycznego. Określenie ceny lub podstaw do jej ustalenia, podobnie jak innych elementów treści czynności prawnej, może bowiem nastapić w jakikolwiek sposób, także dorozumiany. Skoro zatem, jak wynika z ustaleń Sądu, „[...] okoliczności towarzyszące zawarciu umowy pozwalają na przyjęcie zgodnej woli stron związania się ceną przyjętą w stosunkach danego rodzaju", to można przyjaćc, że określenie ceny lub podstaw do jej ustalenia nastapiło w sposób spełniający wymagania wynikające z art. 535 i 536 k.c.

$\mathrm{W}$ odniesieniu do zagadnienia przyznawania $\mathrm{w}$ umowie jednej ze stron uprawnienia do określenia ceny widać pewną liberalizację poglądów w orzecznictwie. Sąd Najwyższy w wyroku z 25 czerwca 2010 r. stwierdził bowiem, że określenie ceny przewidziane art. 536 § 1 k.c. może być dokonane przez jedna ze stron umowy sprzedaży, jeśli skonkretyzowane zostały i uzgodnione warunki i termin wykonania tej czynności ${ }^{22}$. W stanie faktycznym strony zawarły umowę sprzedaży akcji, w której przewidziano możliwość skorygowania ceny przez jej obniżenie, a ewentualna korekta miała być dokonana według wartości aktywów netto wskazanej w bilansie sporządzonym na datę zamknięcia, którą była data zawarcia umowy. Zastrzeżono także, że ostateczna cena, jeśli będą podstawy do obniżenia pierwotnie ustalonej, powinna być przedmiotem potwierdzenia przez strony przez sporządzenie i podpisanie dokumentu „Ostateczna cena nabycia" i tę cenę strony traktować miały jako wartość rynkowa akcji. Sąd Najwyższy uznał za dopuszczalny taki mechanizm ustalania ceny, wskazujac, że: „Upoważnienie do dokonania tego przez jedną ze stron umowy oraz skorzystania przez nią z opinii wskazanego podmiotu, profesjonalisty w dziedzinie weryfikacji bilansów, w sytuacji dokładnego i jednoznacznego określenia podstaw ustalenia ceny oraz terminu, w jakim należało tego dokonać, nie było sprzeczne z obowiązkiem oznaczenia w umowie sprzedaży ceny. Ponadto cenę obniżoną według przyjętych założeń zobowiązały się potwierdzić obie strony. Podkreślenia wymaga, że brak podstaw do obniżenia ustalonej ceny albo nieskorzystanie przez pozwana z uprawnienia do dokonania tego, nie mogło prowadzić do przyjęcia, że nie doszło do skutecznego zawarcia umowy, ponieważ strony były związane ceną pierwotnie ustaloną". Równocześnie Sąd uznał, że niedochowanie terminu oznaczonego w umowie do podjęcia działań mających na celu obniżenie ceny pociaga za sobą obowiązek zapłaty ceny

\footnotetext{
20 I ACr 133/90, Legalis.

21 Tak też Habryn-Chojnacka (2019a): nb. 2 i lit. tam powołana.

22 I CSK 505/09, Legalis. Podobnie Naworski (1999): 31.
} 
ustalonej w umowie (a więc bez jej obniżenia), jest to bowiem swego rodzaju umowny termin prekluzyjny.

Dość liberalne stanowisko co do zasad określenia ceny zajął również Sąd Apelacyjny w Krakowie w wyroku z 16 grudnia $2014 \mathrm{r.}^{23}$, powołując się na uzasadnienie wyroku Sądu Najwyższego z 14 kwietnia 2005 r. ${ }^{24}$ oraz wskazując, że nie można także wykluczyć dopuszczalności ustalenia ceny przez odesłanie do wyceny biegłego (tak Sąd Najwyższy w uzasadnieniu wyroku z 10 lipca 2003 r. $^{25}$ ) i argumentując: „Z przepisów art. $535 \mathrm{KC}$ i $536 \mathrm{KC}$ nie wynika przecież, że elementem konstytuującym umowę sprzedaży jest uzgodnienie wysokości ceny w konkretnej kwocie. Istota zagadnienia sprowadza się natomiast do zgodności intencji stron co do odpłatności oraz uzgodnienie danych pozwalajaccych na ustalenie wysokości ceny, co jest konieczne do dokonania zapłaty. O ile zatem strony wskazuja, że za przejęcie własności rzeczy strona pozwana zapłaci kwotę odpowiadająca wartości rynkowej rzeczy, a zostanie ona ustalona na podstawie wyceny biegłego, to ustalenia te odpowiadają kryteriom określonym w art. $536 \S 1 \mathrm{KC}$. W ocenie SA nie ma przy tym znaczenia, że zgodnie $\mathrm{z}$ wola stron czynności techniczne związane ze zleceniem wyceny zostaną powierzone jednej z nich. W szczególności nie daje to podstaw do konkluzji, że skutkiem zlecenia wyceny przez jedna stronę umowy jest przyjęcie, iż została ona ustalona jednostronnie. Nie budzi bowiem wątpliwości, że gdyby wynikiem wyszacowania wartości sprzedawanej rzeczy przez biegłego w takich warunkach była zapłata wyliczonej kwoty przez druga stronę, to nie byłby kwestionowany tak fakt zawarcia umowy sprzedaży, jak też jej ważność. Odmienną rzeczą jest to, jakie skutki powstają w razie zakwestionowania dokonanej wyceny. [...] W doktrynie podnosi się, że gdy strona zakwestionuje trafność wyceny dokonanej przez osobę trzecią lub nawet przez drugą stronę, powołując się na jej pokrzywdzenie, to umowę należy uznać za nieważną w oparciu o art. $58 \mathrm{KC}$ [...] Kodeks cywilny nie upoważnia bowiem sądu do ustalenia ceny. Prezentowane jest także rozwiązanie, zgodnie z którym niezaaprobowanie przez jedna ze stron wysokości zaproponowanej ceny należy potraktować jako niespełnienie warunku zawieszającego, który polegał na osiagnięciu konsensu co do kwotowego wymiaru ceny [...]”. Taka stanowcza konkluzja może jednak nie być trafna w odniesieniu do wszystkich przypadków tego rodzaju. Strony mogą bowiem przewidzieć i określić w umowie „procedurę” (sposób postępowania) na wypadek zakwestionowania przez kontrahenta ceny wyliczonej przez biegłego; takie rozwiązania umowne wydają się racjonalne. Jest natomiast kwestią wysoce wątpliwa, czy w razie zakwestionowania wyliczeń biegłego, przy braku lub po wyczerpaniu procedury umownej, o jakiej wyżej mowa, strona kwestionująca wycenę może wystapić z powództwem o ustalenie istnienia umownego stosunku prawnego o treści, jaka - zdaniem powoda - obejmować ma cenę prawidłowo ustaloną przez biegłego w postępowaniu sądowym. Wątpliwości mają swoje źródło w tym, czy

\footnotetext{
23 Wyrok SA w Krakowie z 16 grudnia 2014 r., I ACa 980/14, Legalis.

24 II CK 626/04, Legalis.

25 I CKN 487/01, Legalis.
} 
$\mathrm{w}$ opisanej sytuacji istnieje interes prawny w rozumieniu art. 189 k.p.c. czy jedynie interes faktyczny strony kwestionującej prawidłowość wyceny biegłego.

Równocześnie jednak w orzecznictwie twierdzi się, że: „Sprzedający w chwili zawarcia umowy sprzedaży nie może pozostawać w niepewności co do wysokości ceny, jaką otrzyma za towar, gdyż cena stanowi essentialia negotii umowy sprzedaży. Korekta ceny wskazanej w fakturze możliwa jest jedynie w przypadku oczywistej omyłki, nie może natomiast wynikać ze zmiany ceny dokonanej już po zawarciu umowy"26. Podkreślenia jednak wymaga, że wyrok ten dotyczy tzw. opłat półkowych ${ }^{27}$ i dlatego nie jest zasadne nadawanie ogólniejszego znaczenia tezom w nim zawartym.

\section{KLAUZULE EARNOUT ORAZ CLAWBACK JAKO SPOSÓB OKREŚLENIA CENY ZGODNY Z ART. 536 § 1 K.C.}

Oczywiste jest, że żadna z omawianych tu klauzul nie stanowi określenia ceny w sposób stanowczy (wprost). Powstaje więc pytanie, czy klauzule te spełniaja przesłankę drugiego ze sposobów określenia ceny - a więc przez wskazanie podstaw do jej ustalenia.

Sąd Najwyższy stwierdza, że: „Podstawą do ustalenia ceny w sposób określony w art. $536 \S 1 \mathrm{KC}$ mogą być - zależnie od woli stron - okoliczności istniejące w chwili zawarcia umowy, jak również takie, które mogą wystapić dopiero w przyszłości, przeto w razie powstania uzasadnionych wątpliwości dokonanie wykładni woli stron wymaga posłużenia się ustawowymi kryteriami określonymi w przepisach art. $65 \mathrm{KC}^{28}$. Podobnie trafnie SN podkreślił w powołanym już wcześniej wyroku, że obniżenie ustalonej ceny albo nieskorzystanie przez jedna ze stron umowy z uprawnienia do dokonania tego, nie mogło prowadzić do przyjęcia, że nie doszło do skutecznego zawarcia umowy, ponieważ strony były związane ceną pierwotnie ustaloną ${ }^{29}$. Można przyjać, że takie stanowisko daje podstawy do przyjęcia dopuszczalności omawianych klauzul earnout i clawback.

Każdorazowo jednak w okolicznościach konkretnego przypadku klauzula tego rodzaju będzie podlegała wykładni - warto tu podkreślić, w jaki sposób klauzula kalkulacji ceny została określona w umowie, którą analizował SN

${ }^{26}$ Wyrok SA w Warszawie z 4 lipca 2013 r., I ACa 49/13, Legalis.

${ }^{27}$ Zgodnie z art. 15 ust. 1 pkt 4 ustawy o zwalczaniu nieuczciwej konkurencji z 16 kwietnia 1993 r. (t.jedn.: Dz. U. 2019, poz. 1010) czynem nieuczciwej konkurencji jest utrudnianie innym przedsiębiorcom dostępu do rynku, w szczególności przez pobieranie innych niż marża handlowa opłat za przyjęcie towaru do sprzedaży. Sąd uznał, że zarzucane pozwanemu czyny zaliczają się do kategorii niedozwolonych praktyk rynkowych, ograniczających konkurencję między podmiotami gospodarczymi, stypizowanych w art. 15 ust. 1 pkt 4 ww. ustawy.

${ }^{28}$ Wyroki SN: z 2 grudnia 2004 r., V CK 291/04, Legalis; z 25 czerwca 2008 r., III CSK 20/08, Legalis.

${ }^{29}$ Wyrok z 25 czerwca 2010 r., I CSK 505/09, Legalis. 
w wyroku z 2 grudnia 2004 r. ${ }^{30}$ Otóż, jak wynika z uzasadnienia tego wyroku, cena sprzedaży prawa użytkowania wieczystego gruntu została wyraźnie określona, natomiast podstawą ustalenia ceny sprzedaży budynków miała być nie tylko wysokość nakładów poczynionych przez sprzedawcę w celu ich wybudowania, ale także skutek dokonania „potrącenia tak określonej ceny z roszczeniem, jakie będzie przysługiwało sprzedającemu o zwrot tychże nakładów”. Taki sposób określenia ceny w ocenie SN może wywoływać uzasadnione wątpliwości, czy zostały w niej w sposób jednoznaczny, stanowczy i stabilny wskazane podstawy do ustalenia ostatnio wymienionej ceny, co skutkowało przekazaniem sprawy do ponownego rozpoznania przez sąd apelacyjny. Równocześnie SN podkreślił, że: „Kupujący nie może bowiem pozostawać w stanie niepewności co do tego, czy posiada wystarczające środki finansowe na dokonanie transakcji handlowej, a w konsekwencji należy uznać taką klauzulę za niedopuszczalna, a umowę za niezawartą". To ostatnie stwierdzenie, zawarte w tym samym wyroku, odczytywane literalnie i w oderwaniu od innych wypowiedzi SN, można niestety traktować jako przeciwwskazanie do wprowadzania klauzul earnout oraz clawback do umów sprzedaży - klauzule te bowiem, jak wcześniej wspomniano, zawsze pozostawiają kupującego lub sprzedawcę w niepewności co do ostatecznej wysokości ceny.

W literaturze przyjmuje się dopuszczalność tego typu klauzul w umowie sprzedaży, natomiast w odniesieniu do nieruchomości zauważa się: „Z powyższego wynika, że zmiana ceny po dokonaniu sprzedaży nieruchomości i przeniesieniu praw do niej nie jest możliwa wprost. W celu dokonania stosownego rozliczenia finansowego należy wykreować tytuł prawny do dokonania płatności, np. zawierając umowę agencyjna, umowę o zarządzanie nieruchomością (w przypadku mechanizmu earnout) lub wprowadzić system kar umownych lub odszkodowań (w przypadku clawback)" 31 . Natomiast w odniesieniu do zbycia przedsiębiorstwa podkreśla się, że: „Jak się wydaje, w ramach dyspozycji art. $536 \S 1 \mathrm{KC}$ klauzulę »earn-out» uznać należy za dopuszczalną. Stosując ja, strony wskazuja bowiem w umowie podstawy do ustalenia ceny ostatecznej, o czym expressis verbis stanowi wspomniany przepis" 32 .

Należy przyjąć, że klauzule earnout oraz clawback spełniają przesłankę określenia ceny w sposób zgodny z art. $536 \S 1$ k.c., a więc przez wskazanie podstaw do jej ustalenia ${ }^{33}$. Wynika to z następujących względów.

W pierwszej kolejności podkreślenia wymaga, że w przypadku klauzuli earnout cena w umowie jest określona - cena „podstawowa” - a więc cena,

${ }^{30}$ Wyrok SN z 2 grudnia 2004 r., V CK 291/04, Legalis.

31 Maciak (2014): 44.

32 Drapała (2002): 14. Podobnie autor ten wypowiada się co do tzw. klauzul dopasowujących (Anpassungsklausel), której odpowiednikiem jest clawback.

33 Analizy wymaga także inna kwalifikacja tych klauzul, a mianowicie uznanie ich za warunek w rozumieniu art. 89 k.c. Strony, wprowadzając taką klauzulę (warunek) do umowy, uzależniałyby powstanie skutku (i) w postaci zmiany ceny (automatycznej) lub (ii) w postaci powstania zobowiązania do zmiany ceny (zob. pkt V) od określonych zdarzeń przyszłych (np. komercjalizacji powierzchni). Wydaje się jednak, że nie można tu mówić o samym warunku - warunek ten jest po prostu wkomponowany w mechanizm określania ceny z art. $536 \S 1$ k.c. 
która ma zostać zapłacona. W tym więc zakresie na pewno nie można stawiać zarzutu, że cena w ogóle nie jest określona. Cena bowiem jest w umowie oznaczona, a co najwyżej może zostać podwyższona na zasadach określonych w klauzuli earnout, natomiast nie może ulec obniżeniu ${ }^{34}$ (co nie wyłącza możliwości jej obniżenia na podstawie drugiej z omawianych klauzul, a mianowicie klauzuli clawback - o ile taki mechanizm zostanie przyjęty w umowie).

Oczywiście, jak już wcześniej wspomniano i co wynika z orzecznictwa, taka klauzula każdorazowo będzie podlegała wykładni. W szczególności $\mathrm{w}$ razie sporu sąd będzie badał, czy klauzula jest wystraczająco precyzyjna, a w konsekwencji, czy pozwala na określenie kwoty, o jaką cena ma być podwyższona. Według SN ${ }^{35}$ jedyną konsekwencją braku jej precyzyjnego określenia jest związanie stron pierwotną ceną określoną w umowie sprzedaży, natomiast nie byłoby zasadne twierdzenie, że w takim przypadku cena w ogóle nie została w umowie określona (ze wszystkimi tego konsekwencjami). Wydaje się jednak, że takie postawienie sprawy nie jest właściwe - w przypadku gdy klauzula nie jest precyzyjna, podlega ona bowiem wykładni zgodnie z art. 65 k.c. Wykładnia ta prowadzić musi do określenia zamierzonego przez strony znaczenia danej klauzuli i w konsekwencji do jej zastosowania w takim właśnie kształcie. Stąd strony mogą pozostać związane pierwotna cena określoną w umowie sprzedaży (jak to wskazał Sąd Najwyższy) tylko w przypadku, gdy nie zostały spełnione przesłanki podwyższenia ceny wskazane w tej klauzuli bądź gdy wykładnia doprowadzi do wniosku o bezskuteczności klauzuli (o czym dalej).

Nieco bardziej skomplikowana wydaje się sytuacja w odniesieniu do klauzuli clawback. Wynika to z tego, że w przypadku implementowania do umowy tego typu klauzuli strony co prawda określają cenę, jednak to właśnie ta cena ma podlegać ewentualnemu obniżeniu. W konsekwencji żadna ze stron w chwili zawarcia umowy nie zna ceny (choćby minimalnej), którą zapłaci/ uzyska. Wydaje się jednak, że także taki sposób określenia ceny mieści się w ramach dyspozycji art. $536 \S 1$ k.c., najistotniejsze zaś jest tu precyzyjne sformułowanie analizowanej klauzuli. Wszak z samej regulacji art. $536 \S 1$ k.c. wynika, że w chwili zawarcia umowy cena nie musi być w ogóle stronom znana i jest to istota tego sposobu określenia ceny. Tym bardziej więc za dopuszczalne należy uznać określenie przesłanek i mechanizmu obniżenia ceny, która jest w umowie wskazana. Także SN nie miał wątpliwości co do dopuszczalności takiej klauzuli ${ }^{36}$. By uniknąć wszelkich wątpliwości, można jednak postulować wprowadzenie do umowy w takim przypadku ceny minimalnej tj. ceny, poniżej której obniżenie nie jest już dopuszczalne.

Podkreślenia wymaga także, że nie ma przeciwwskazań, by w umowie zastosowanie znalazły obie te klauzule jednocześnie - tzn. by strony określiły, kiedy cena wzrośnie, a kiedy będzie podlegała obniżeniu.

${ }^{34}$ Oczywiście nie chodzi tu o obniżenie ceny w przypadku, gdy ziszczą się przesłanki odpowiedzialności z tytułu rękojmi za wady rzeczy sprzedanej.

35 Wyrok z 25 czerwca 2010 r., I CSK 505/09, Legalis.

36 Wyrok SN z 25 czerwca 2010 r., I CSK 505/09, Legalis. 


\section{SPOSÓB REALIZACJI KLAUZUL EARNOUT LUB CLAWBACK (AUTOMATYCZNA ZMIANA CENY CZY ZMIANA UMOWY)}

Wreszcie, analizy wymaga, czy dla skuteczności którejkolwiek z przedstawionych tu klauzul konieczne jest postanowienie w umowie, że po wyliczeniu nowej ceny (zgodnie z daną klauzula) strony „zgodnie potwierdzą tę cenę” (takie postanowienia są często stosowane w umowach) bądź zostanie zawarta umowa zmieniająca umowę pierwotna - przez zmianę ceny, czy też możliwe jest automatyczne obniżenie albo podwyższenie ceny.

Nie jest jasne, czy w stanie faktycznym sprawy, która rozpoznawał $\mathrm{SN}^{37}$, strony uzgodniły, że po ustaleniu ceny zawrą umowę zmieniająca umowę sprzedaży, czy też że potwierdzą zgodnie tę nową cenę (z uzasadnienia wyroku SN wynika: „Strony ustaliły, że jeśli wartość aktywów netto ustalona na podstawie bilansu na datę zawarcia umowy ostatecznej byłaby niższa niż $3000000 \mathrm{zł}$, to ustalona w umowie cena zostanie obniżona oraz zobowiązały się potwierdzić na piśmie ostateczną cenę akcji przez podpisanie dokumentu "Ostateczna cena nabycia“"). Jak się wydaje, samo „potwierdzenie” nowej ceny (po jej ponownym obliczeniu zgodnie z klauzulą earnout lub clawback), nie jest bowiem równoznaczne z zawarciem umowy zmieniającej pierwotną umowę, jednak jest to postanowienie niejasne i wymaga wykładni oświadczeń woli stron. Ostatecznie sąd może dojść do wniosku, że używając takiego sformułowania, strony miały na celu zawarcie właśnie umowy zmieniajaccej. W praktyce zwykle sporządza się tzw. porozumienia, w których ustala się ostateczna cenę - nie stosuje się w nich jednak sformułowania, że jest to zmiana pierwotnej umowy. Spotykane są także rozwiązania, gdzie w umowie przewiduje się obowiązek zawarcia umowy zmieniającej (tzw. aneksu) w określonym terminie, w której to umowie strony określą podwyższoną (obniżona) cenę.

Odpowiadając na postawione pytanie, należy wskazać, że w przypadku zastosowania w umowie sprzedaży klauzli earnout lub clawback nie jest konieczna zmiana umowy - tzn. obniżenie ceny albo jej podwyższenie może nastapić automatycznie (oczywiście po spełnieniu określonych w umowie warunków). Każdorazowo umowa powinna jednak jednoznacznie przewidywać mechanizm i terminy rozliczeń w takiej sytuacji, a może określać także termin, w którym strona umowy może z tego mechanizmu skorzystać. Przy czym bezskuteczny upływ terminu skutkuje uzyskaniem przez cenę określoną w umowie charakteru ceny ostatecznej (a więc nie podlegającej dalszym zmianom).

Natomiast jeśli już strony wprowadzą do umowy obowiązek zawarcia umowy zmieniającej umowę pierwotna, w której to umowie zmieniającej cena ma zostać na nowo określona, termin zapłaty zaś będzie biegł dopiero od jej zawarcia, powstaje pytanie o znaczenie takiej klauzuli.

Przede wszystkim analizy wymaga, czy w takim przypadku można uznać, że w istocie w umowie sprzedaży została zawarta przedwstępna umowa do zawarcia umowy zmieniającej pierwotną umowę sprzedaży, a w razie

${ }^{37}$ Wyrok z 25 czerwca 2010 r., I CSK 505/09, Legalis. 
uchylania się przez drugą stronę od zawarcia takiej umowy, możliwe jest dochodzenia roszczenia na podstawie art. 64 k.c. Problem ten był analizowany przez SA w Krakowie ${ }^{38}$. Jak wynika ze stanu faktycznego sprawy rozpoznawanej przez ten sąd, sprzedawca (pozwany) zobowiązał się zwrócić na rzecz kupującego (powód) różnicę między ceną sprzedaży wynikającą z aktu notarialnego a ceną wynikajacca z wyliczenia iloczynu 1800 zł i powierzchni użytkowej mieszkalnej planowanego budynku mieszkalnego - w sytuacji, jeżeli w wyniku wydanego pozwolenia na budowę powierzchnia użytkowa mieszkalna planowanego budynku pomniejszy się. Świadczenie to pozwany zobowiązał się spełnić w terminie siedmiu dni, licząc od dnia zawarcia umowy zmieniajaccej (strony wskazały: aneksu) do umowy sprzedaży.

Zdaniem SA strony zobowiązywały się do zawarcia umowy zmieniającej, na podstawie której miały ostatecznie ustalić cenę sprzedaży, bazując na faktycznej powierzchni użytkowej mieszkalnej wynikającej z ostatecznej decyzji o pozwoleniu na budowę. W konsekwencji sąd przyjął, że niezawarcie (nieprzystapienie) przez jedną ze stron (pozwanego) takiej zamieniającej umowy stanowi niewykonanie obowiązków umownych i naruszenie art. 354 $\S 1$ k.c. W ocenie SA dopiero zawarcie takiej umowy zmieniajacej dawałoby podstawę do domagania się przez powódkę od pozwanego zapłaty kwoty stanowiącej różnicę między ceną sprzedaży wynikająca z aktu notarialnego a ceną wynikająca z wyliczenia iloczynu 1800 zł i powierzchni użytkowej mieszkalnej planowanego budynku mieszkalnego. Nie oznacza to jednak, że SA powództwo oddalił - wręcz przeciwnie: zasądził od pozwanego kwotę, jaka wynikała z korekty ceny, ale nastapiło to tytułem odszkodowania. Sąd Apelacyjny uznał, że nie jest możliwe zawarcie umowy przedwstępnej do umowy zamieniajacej umowę sprzedaży (która to umowa zmieniajacca miałaby zmieniać cenę sprzedaży; taki argument był podnoszony przez pozwanego). Wynika to - w ocenie SA - przede wszystkim z tego, że w doktrynie zgodnie przyjmuje się zasadę, iż nie należy domniemywać zawierania umów przedwstępnych, a w razie wątpliwości należy przyjmować, iż strony łączy umowa stanowcza a nie przedwstępna. Co więcej, zdaniem SA: „zapis $§ 6$ Umowy Sprzedaży nie wprowadza zobowiązania do zawarcia innej, oznaczonej umowy ale zobowiązanie do zmiany w przyszłości wyłącznie jednego elementu uprzednio zawartej umowy definitywnej tj. zmiany ceny sprzedaży. Wbrew stanowisku powoda zobowiązanie do zawarcia aneksu nie może być tożsame z zawarciem odrębnej umowy. Aneks na gruncie przedmiotowej sprawy nie ma charakteru samoistnego i nie kreuje zamierzonego, głównego celu gospodarczego, jakim była sprzedaż praw do nieruchomości. Jak już wskazuje literalna wykładania oraz zasady logiki, zobowiąanie do zawarcia aneksu do umowy (aneksowania umowy) to zobowiązanie do zmiany istniejacej umowy w pewnym zakresie, a nie nawiązania nowego stosunku prawnego. Postanowienie $§ 6$ Umowy Sprzedaży nie stanowi odrębnej umowy i nie może istnieć niezależnie od Umowy Sprzedaży - nie jest bowiem odrębnym bytem, ale jednym z jej elementów tzn. uregulowaniem sposobu zmiany tej

${ }^{38}$ Wyrok SA w Krakowie z 8 maja 2018 r., I ACa 909/17, Legalis. 
Umowy w zakresie ceny. Umowa Sprzedaży została zawarta, a prawo użytkowania wieczystego nieruchomości zostało przeniesione. Wraz z zawarciem tej Umowy urzeczywistnił się jej skutek rzeczowy, który był głównym celem gospodarczym zawarcia kontraktu. W związku z powyższym, sam $§ 6$ Umowy Sprzedaży nie może stanowić podstawy do zawarcia odrębnej umowy, gdyż nie ma charakteru samoistnego. Tym samym nie może on być interpretowany jako umowa przedwstępna i wywoływać charakterystyczne dla niej skutki”.

Wydaje się jednak, że takie postawienie sprawy nie jest właściwe. Brak bowiem podstaw stanowiska, że nie można zawrzeć umowy przedwstępnej do umowy zamieniającej i że sama umowa przedwstępna nie może stanowić niejako części innej umowy ${ }^{39}$. Jak podkreśla się w literaturze, w umowie przedwstępnej można się zobowiązać do zawarcia każdej umowy obligacyj$n e{ }^{40}$. Niewątpliwie umowa zmieniająca umowę pierwotną także jest umową. Brak więc podstaw, by twierdzić, że umowa przedwstępna może poprzedzać jedynie właściwe umowy (ale już nie umowy je zmieniające), jak to wskazał SA. Rację ma natomiast Sąd, wskazując, że nie można domniemywać zawarcia przez strony umowy przedwstępnej. W tym więc zakresie podstawowe znaczenie ma wykładnia postanowień umowy, której w toku procesu sąd dokonuje na podstawie zeznań świadków, dokumentów z etapu negocjowania umowy oraz przesłuchania stron. Przede wszystkim jednak podkreślenia wymaga, że aby można było mówić o umowie przedwstępnej, musi ona spełniać wymogi określone w art. 389 k.c., a więc powinna określać istotne postanowienia umowy przyrzeczonej, przez które rozumie się co najmniej essentialia negotti ${ }^{41}$. Przyjmuje się, że w przypadku umowy sprzedaży musi to więc być cena bądź podstawy do jej określenia zgodnie z art. $536 \S 2$ k.c. ${ }^{42}$ Tym samym także umowa przedwstępna do umowy zmieniającej umowę sprzedaży musi spełniać te przesłanki, a jeśli tak nie jest, jest nieważna. Wreszcie podkreślenia wymaga, że zakwalifikowanie postanowienia umownego jako umowy przedwstępnej ma duże znaczenie praktyczne. W braku skutku silniejszego takiej umowy (art. $390 \S 2$ k.c.) obowiązek odszkodowawczy jest bowiem ograniczony do tzw. negatywnego interesu umownego (art. 390 § 1 k.c.). Stąd wydaje się, że w praktyce uznanie klauzuli umownej wskazującej na konieczność zawarcia umowy zmieniającej umowę sprzedaży przez określenie na nowo ceny za umowę przedwstępną będzie rzadkością.

Powstaje więc pytanie o inną kwalifikację takiej klauzuli i jej skutki. Po pierwsze, można przyjąć, że klauzula taka - ponieważ czyni wymagalność roszczenia o zapłatę zależna od woli dłużnika (od tego, czy zawrze on umowę zmieniająca) za sprzeczną z właściwością (natura) stosunku zobowiązaniowego. Narusza ona bowiem równowagę kontraktowa, przyznając wyłącznie jednej ze stron możliwość decydowania o tym, czy i kiedy roszczenie będzie wymagalne.

\footnotetext{
39 Strugała (2013): 147; (2012): 1228.

${ }^{40}$ Krajewski (2000): 75.

41 Krajewski (2000): 102.

${ }^{42}$ Zob. przyp. 14.
} 
Nieważność takiej klauzuli skutkuje koniecznością sięgnięcia do art. 58 § 3 k.c. i ustalenia, czy bez postanowień dotkniętych nieważnością umowa sprzedaży zostałaby zawarta.

Po drugie, możliwe jest przyjęcie jako wyniku wykładni, że klauzula taka nie jest skuteczna - jeśli wolą stron nie było uzależnienie wymagalności roszczenia o zapłatę od zawarcia umowy zmieniającej. Byłby to więc skutek, o jakim najprawdopodobniej wspomniał SN w jednym z powołanych już wcześniej wyroków ${ }^{43}$.

Po trzecie, możliwe jest uznanie omawianej klauzuli uzależniającej zapłatę od zawarcia umowy zmieniającej za konstrukcję podobną do warunku, co uzasadniałoby zastosowanie przez analogię art. $93 \S 1$ k.c., zgodnie z którym jeżeli strona, której zależy na nieziszczeniu się warunku, przeszkodzi w sposób sprzeczny z zasadami współżycia społecznego ziszczeniu się warunku, następują skutki takie, jakby warunek się ziścił. W konsekwencji roszczenie o zapłatę byłoby wymagalne (mimo niezawarcia umowy zmieniającej).

\section{KLAUZULE EARNOUT ORAZ CLAWBACK JAKO WARUNEK}

Wreszcie, analizy wymaga, czy w przypadku wprowadzenia do umowy sprzedaży nieruchomości klauzul earnout oraz clawback można zasadnie twierdzić, że umowa ta jest umową warunkowa, a konkretniej - czy przeniesienie własności nieruchomości następuje w takim przypadku pod warunkiem. Przyjęcie takiego stanowiska skutkowałoby - ze względu na regulację art. 157 k.c. - brakiem możliwości zamieszczania takich klauzul w umowach sprzedaży przenoszących własność nieruchomości (umowa taka wywołałaby tylko skutek zobowiązujacy).

By odpowiedzieć na postawione pytanie, w pierwszej kolejności analizy wymaga istota warunku. Ze względu na ramy niniejszego opracowania wystarczające jest w tym miejscu stwierdzenie, że warunek stanowi sposób ukształtowania skuteczności czynności prawnej przez jej strony powodując odsunięcie w czasie zamierzonych przez strony skutków prawnych ${ }^{44}$. Przy czym, jak trafnie podkreśla się w literaturze, strony mogą ukształtować jako warunkowe wszystkie lub tylko niektóre skutki czynności prawnej ${ }^{45}$. Tym samym, by można było mówić o warunkowym przeniesieniu własności nieruchomości, to właśnie skutek czynności prawnej w postaci przeniesienia tej własności musiałby zostać uzależniony od ziszczenia się określonego warunku.

W konsekwencji należy przyjąć, że brak podstaw, by wprowadzenie do umowy sprzedaży nieruchomości klauzul earnout lub clawback traktować jako zastrzeżenie warunku, od którego ziszczenia uzależnione byłoby przeniesienie własności nieruchomości. Należy bowiem podkreślić, że choć co do

\footnotetext{
43 Wyrok z 25 czerwca 2010 r., I CSK 505/09, Legalis.

44 Zawadzka (2012): 124. Por. Swaczyna (2012): 29-30.

45 Zawadzka (2012): 125.
} 
zasady ze względu na wzajemny charakter umowy sprzedaży zapłata ceny powinna nastapić równocześnie z wydaniem rzeczy przez sprzedawcę, dopuszczalne jest $\mathrm{w}$ tym względzie wprowadzenie do umowy odmiennych zasad rozliczeń (art. 488 § 1 k.c.) ${ }^{46}$. W szczególności, często stosowanym w praktyce i niebudzącym wątpliwości rozwiązaniem jest uzależnianie zapłaty ceny od upływu określonego terminu bądź też rozłożenie ceny na raty. Co więcej, zapłata ceny, podobnie zreszta jak i wydanie rzeczy, jest jedynie zdarzeniem będącym przejawem wykonania umowy sprzedaży, w związku z czym nie ma wpływu na ocenę jej ważności. Umowa ta ma bowiem charakter umowy konsensualnej i o tym, czy doszło do jej zawarcia, decyduje wyłącznie złożenie zgodnych oświadczeń woli stron ${ }^{47}$, o ile zaś strony inaczej nie postanowiły, własność rzeczy sprzedanej oznaczonej co do tożsamości przechodzi na kupującego w wyniku samego zawarcia umowy, niezależnie od tego, czy cena została uiszczona (art. $155 \S 1 \mathrm{w}$ zw. z art. $535 \S 1$ k.c.) ${ }^{48}$. Należy również podkreślić, że w orzecznictwie nie dostrzeżono problemu sprzeczności zamieszczania takich klauzul z art. 157 k.c. ${ }^{49}$

\section{PODSUMOWANIE}

Jak wynika z przeprowadzonej analizy, w prawie polskim brak przeszkód do stosowania w umowach sprzedaży klauzul earnout oraz clawback, a dotyczy to także umów sprzedaży nieruchomości. Klauzule te znakomicie ułatwiają obrót, pozwalając obu stronom uzyskać równowagę kontraktowa. Oczywiście w okolicznościach konkretnej sprawy dana klauzula - zredagowana wadliwie - może zostać uznana za nieskuteczną bądź nieważną. Tym bardziej konieczna jest więc precyzja przy formułowaniu tych postanowień w umowie.

Drapała, P. (2002). Klauzula „earn-out” i inne postanowienia dotyczące ceny sprzedaży, [w:] Wybrane problemy cywilnoprawne w transakcjach typu ,asset deal” i ,share deal”. Monitor

Prawniczy 23: 10-16.

Gizbert-Studnicki, T. (1975). O nieważnych czynnościach prawnych w świetle koncepcji czynności konwencjonalnych. Państwo i Prawo 30(4): 70-82.

Gutowski, M. (2008). Nieważność czynności prawnej. Warszawa.

Haładyj, K., Tulibacka, M. (2020a). Komentarz do art. 535, [w:] K. Osajda (red.), Kodeks cywilny. Komentarz. Wyd. 27. Legalis/el.

Haładyj, K., Tulibacka, M. (2020b). Komentarz do art. 536, [w:] K. Osajda (red.), Kodeks cywilny. Komentarz. Wyd. 27. Legalis/el.

Habryn-Chojnacka, E. (2019a). Komentarz do art. 535, [w:] Gutowski M. (red.), Kodeks cywilny. Tom 2: Komentarz. Wyd. 2. Legalis/el.

${ }^{46}$ Haładyj, Tulibacka (2020a): nb. 62.

47 Wyrok SA w Białymstoku z 16 września 2016 r., I ACa 304/16, Legalis.

48 Wyrok SA w Krakowie z 8 maja 2018 r., I ACa 1344/17, Legalis.

49 Zob. wyrok SA w Krakowie z 13 listopada 2014 r., I ACa 1092/14, Legalis. Co do innych zarzutów stron kwestionujących ważność postanowienia określającego cenę zob. wyrok SA w Krakowie z 8 maja 2018 r., I ACa 909/17, Legalis. 
Habryn-Chojnacka, E. (2019b). Komentarz do art. 536, [w:] M. Gutowski (red.), Kodeks cywilny. Tom 2: Komentarz. Wyd. 2. Legalis/el.

Jasińska, K. (2019). Komentarz do art. 536, [w:] M. Załucki (red.), Kodeks cywilny. Komentarz. Wyd. 2. Legalis/el.

Jezioro, J. (2019a). Komentarz do art. 535, [w:] E. Gniewek, P. Machnikowski (red.), Kodeks cywilny. Komentarz. Wydanie 9. Legalis/el.

Jezioro, J. (2019b). Komentarz do art. 536, [w:] E. Gniewek, P. Machnikowski (red.), Kodeks cywilny. Komentarz. Wydanie 9. Legalis/el.

Karasek, I. (2005). Klauzule dotyczące oznaczenia ceny, [w:] M. Chudzik, I. Karasek, K. Kohutek, B. Łyszczarz, M. Olczyk, M. Porzycki, D. Rogoń, M. Rusinek, W. Żukowski, Sprzedaż, Rozdział 2: Klauzule dotyczace zobowiązania do zapłaty ceny oraz odsetek. Lex/el.

Katner, W.J. (2008). Cena i inne oznaczenia rzeczy (towaru) w umowie sprzedaży, [w:] M. Pazdan, W. Popiołek, E. Rott-Pietrzyk, M. Szpunar (red.), Europeizacja prawa prywatnego. Tom 1. Warszawa: 541-562.

Katner, W.J. (2017). Umowy w obrocie towarowym, [w:] M. Stec (red.), System prawa handlowego. Prawo umów handlowych. Warszawa: 938-1069.

Korzonek, J., Rosenbluth, I. (1936). Kodeks zobowiązań. Komentarz. Tom 1. Kraków.

Kozioł, A. (2018). Komentarz do art. 535, [w:] M. Fras, M. Habdas (red.), Kodeks cywilny. Komentarz. Tom 4: Zobowiazzania. Część szczególna (art. 535-764(9)), Lex/el.

Krajewski, M. (2000). Umowa przedwstępna. Warszawa.

Machnikowski, P. (2005). Swoboda umów według art. $353^{1}$ KC. Konstrukcja prawna. Warszawa.

Maciak, Ł. (2014). Earnout i Clawback na rynku nieruchomości w Polsce. Nieruchomości 8: 43-45.

Naworski, J.P. (1999). Cena. Obowiązek zapłaty w obrocie gospodarczym. Warszawa.

Poźniak-Niedzielska, M. (2000). Klauzula earn out czyli uzupełnienie ceny przedsiębiorstwa w późniejszym czasie. Rejent 7/8: 13-22.

Skapski, J. (1976). § 9 II Ustalenie ceny, [w:] S. Grzybowski (red.), System prawa cywilnego. Prawo zobowiązań. Część szczegółowa. Tom 3. Część 2. Ossolineum: 49-54.

Strugała, R. (2012). Znaczenie prawna klauzul renegocjacyjnych. Monitor Prawniczy 22: 1227-1230.

Strugała, R. (2013). Standardowe klauzule umowne: adaptacyjne, salwatoryjne, merger, interpretacyjne oraz pactum de forma. Warszawa.

Swaczyna, B. (2012). Warunkowe czynności prawne. Warszawa.

Trzaskowski, R. (2017). Komentarz do art. 535, [w:] J. Gudowski (red.), Kodeks cywilny. Komentarz. Tom 4: Zobowiązania. Część szczegółowa. Wyd. 2. Lex/el.

Werner, R. (2012). Earn-Out-Klauseln - Kaufpreisanpassung beim Unternehmenskauf. Das deutsche Steuerrecht 2012: 1662-1667.

Więzowska-Czepiel, B. (2014). Komentarz do art. 536, [w:] B. Kaczmarek-Templin, P. Stec, D. Szostak (red.), Ustawa o prawach konsumenta. Kodeks cywilny (wyciag). Komentarz. Wyd. 1. Warszawa. Legalis/el.

Vischer, M. (2002). Earn out-Klauseln in Unternehmenskaufvertägen. Süddeutsche Juristen-Zeitung 21: 509-517.

Zawadzka, J. (2012). Warunek w prawie cywilnym. Warszawa.

\section{EARNOUT AND CLAWBACK CLAUSES IN REAL ESTATE SALES CONTRACTS}

Sum mary

The earnout and clawback clauses are often used by the parties in sales contracts. These clauses provide for price flexibility in the agreements and as a result they are of crucial legal and commercial importance for the parties. The issue which should be analysed is the admissibility of introducing these clauses in sales contracts pertaining to real properties (perpetual usufruct right). It is result of regulation contained in Article 157 of the Civil Code pursuant to which the ownership of a real property cannot be transferred conditionally or with the stipulation of a time limit. If these clauses fulfil the premises of a condition, they could not be applied in sales contracts aimed at transferring the ownership of real property to the buyer. The aim of the article is to find an answer to this question. The conducted research leads to the conclusion that both earnout and 
clawback clauses are compatible with the way of determining of a price according to Article 536 $\S 2$ of the Civil Code and are admissible under Polish law. Both clauses are also admissible in sale agreements concerning real property - they cannot be treated like a condition (Article 157 of the Civil Code). As a consequence, sale agreements containing such clauses transfer the ownership of the real estate to the buyer.

Keywords: conditional legal act; earnout clause; clawback clause; price; setting of a price; modification of a price 